\title{
The Influential Factor of Family Resilience: Awareness of Islamic Law on Family
}

\author{
Muhammad Asrorun Niam Sholeh ${ }^{1}$, Nopriadi Saputra ${ }^{2}$, Adler Haymans Manurung ${ }^{3}$ \\ ${ }^{1}$ UIN Syarif Hidayatullah, Jakarta - Indonesia \\ ${ }^{2}$ Bina Nusantara University, Jakarta - Indonesia \\ ${ }^{3}$ Bina Nusantara University, Jakarta - Indonesia \\ Email: ${ }^{1}$ asrorun.niam@uinjkt.ac.id, ${ }^{2}$ nopriadi.saputra@binus.ac.id, ${ }^{3}$ adler.manurung@binus.ac.id
}

\begin{abstract}
Covid-19 as worldwide pandemic which lead to health crisis in physical, mental, and also financial dimension is demanding resilience of family. This article is an attempt to examine resilience of family as social system and to assess impact of the Islamic law awareness and other factors on family resilience. This article is based on quantitative and cross-sectional study which involved 296 young people and family as respondents from all-over Indonesia. The collected data was analyzed by PLS SEM approach and analyzed by SmartPLS version 3 for statistical testing. The result explained that family resilience is influenced by the awareness of Islamic law on marriage, parenting quality, and personal financial management. The awareness also impacts on personal financial management and parenting quality. By leveraging awareness of Islamic law in young people and family, it is going to improve the family resilience during Covid 19 crisis
\end{abstract}

Keywords: Islamic Law on Marriage, Family Resilience, Parenting Quality, Personal Financial Management,

\section{Introduction}

Since February 2020 Covid-19 pandemic has hit the world, and Indonesia is one of the countries affected by the spread of the Corona virus. This pandemic disrupts economic stability, social, and children's education in Indonesia (Susilowati \& Azzasyofia, 2020). The family as the smallest social system is the main guard that can protect children from various damaging influences during the existing social dynamics. When the COVID-19 pandemic hitting the world, young Indonesian families were also affected by various negative impacts. It is ranging from social limitation, job loss, physical health, moral and mental and crisis, financial difficulty, disturbance on family harmony, and many other damaging situations (Kasdi \& Saifudin, 2020).

Family resilience as family capability to survive and rebound from traumatic life challenges (Walsh, 2016) is becoming an essential issue. A optimal and good family resilience can assure the survival of the family in surviving and struggling from various problems and difficulties faced by the family (Kasdi \& Saifudin, 2020). This article is an attempt to examine the family resilience and its influential factors. Is family resilience impacted by the awareness of Islamic law on marriage? Is it the most influential factor on family resilience? Those are two main research questions need to be answered through empirical testing.

There are other factors which are hypothesized as the influential factors on family resilience too. Those are personal financial management, parenting quality, reproductive health, and psychological maturity. Those factors are the subjects of course materials of Pendidikan Kepemimpinnan Pemuda dalam Rumah Tangga (PKPRT). This program is a leadership development program for the selected youth from all over Indonesia which is conducted in 2019 by Kemenpora - Indonesia ministry on the youth and sport. The result of this study is useful for developing the next learning programs for improving resilience of families in Indonesia during and after Covid-19 crisis.

\section{Literature Review}


This article is supported by six conceptual constructs: (1) family resilience, (2) Islamic laws on marriage, (3) personal financial management. (4) reproductive health, (5) psychological maturity, and (6) parenting quality. The following paragraphs will discuss those concepts deeply.

Family Resilience (FRES) is defined as the capability of a family to survive and rebound from traumatic life challenges (Walsh, 2016) by maintaining its integrity as family unit (McCubbin \& McCubbin, 1991) and by managing resources to solve the problems and to aim the family welfare goal (Sunarti, 2015). Family resilience is reflected into six dimensions: (1) ability to make meaning of adversity (2) maintaining a positive outlook, (3) utilizing social and economic resources, (4) family connectedness, (5), family spirituality, and (6) family communication and problem solving (Nadrowska, Blazek, \& LewandowskaWalter, 2020).

Awareness of Islamic Law on Marriage (AISL) is defined as personal acceptance or positive perception on Islamic law and regulation of marriage and family life as a Muslim in Indonesia. Based on Modul 1 Hukum Perkawinan (Sholeh, et al., Modul 1 Hukum Perkawinan - Pendidikan Kepemimpinan Pemuda dalam Rumah Tangga, 2019) Islam law on marriage as variable on this article is reflected into four dimensions: (1) marriage pre-requisites, (2) marriage pillars, (3) husband-wife relationship and (4) providing a living for the family (Sholeh, 2008).

Previous qualitative and exploratory study which interviewed 10 family dyads with spinal cord injury (SCI) explained that spirituality after SCI plays an important role for both the family members and the injured individual. Families draw upon spirituality sources, and these sources of spirituality may assist the family resilience to move forward together after SCI (Jones, Dorsett, Simpson, \& Briggs, 2018) Based on the study, this article supposes to examine the impact of Islamic law awareness as source of spirituality on family resilience during Covid-19 crisis.

H1: Awareness of Islamic law on marriage impacts significantly on family resilience.

Parenting Quality (PARQ) plays a strategic role in the growth and development of children, especially in early childhood period. Parenting is a multi-faceted task (Verhoeven, Dekovic, Bodden, \& van Baar, 2017). Parenting quality requires knowledge, commitment, and time of the parents to gather with the children (Sholeh, et al., 2019). Conceptualization of parenting quality consists of five main domains: stimulation, support, harsh discipline, structure, and positive discipline (Verhoeven, Dekovic, Bodden, \& van Baar, 2017)

Empirical study which involved 140 adolescents in India revealed that authoritative parenting style is related to the higher resilience (Firoze \& Sathar, 2018). Another empirical study which involved 123 early adolescents in USA revealed there is significant associations of positive parenting to effortful resilience and control (Nair, Taylor, Evich, \& Jones, 2020). Based on those empirical evidences, this article supposes to examine the impact of parenting quality on family resilience.

H2: Parenting quality impact significantly on family resilience.

Psychological Maturity (PMAT) is defined simply as "the readiness or aptitude for reaching mental health" (Danielewica-Mucha, 1991). Other scholar defined psychological maturity is 
associated with psycho- an individual's socio-emotional competence, social maturity or adaptive functioning which is indicated perspective, temperance, and responsibility (Bryan-Hancock \& Casey, 2010). Based on those scholars' definition, this article defines psychological maturity as psycho-social readiness for being independent, responsible, and confident. Psychological maturity is described into three dimensions: (1) self-reliance - as the person's willingness to take the initiative, without allowing others to exercise excessive control (2) work orientation as individual's willingness to fulfill his or her own obligations and (3) identity - as adolescent's knowledge of him or herself (Morales-Vives, Camps, \& Duenas, 2020).

Empirical study which involved 100 rescue workers in Pakistan as the respondents revealed that between psychological distress impact on resilience negatively and significantly (Yasien, Nasir, \& Shaheen, 2016). Based on the empirical evidence, this article needs to test impact of psychological maturity on family resilience.

H3: Psychological maturity impact significantly on family resilience.

Reproductive Health (REPH) is defined in Undang-Undang no 36, 2009 as "physical, mental, and social health which is related to reproductive systems, functions and processes. It does not mean solely free from disabilities or diseases related to reproductive functioning. Every Indonesia citizen has a right to obtain effective, safe, and affordable reproductive health services. Reproduction health services consist of maternal and child health, family planning, prevention and management of sexually transmitted infections, adolescent reproductive health, prevention and management of abortion complications, prevention and management of infertility, elderly reproductive health, early detection of reproductive cancers and other reproductive health such as sexual violence (Sholeh, et al., 2019). As variable, reproductive health is reflected into three dimensions: (1) healthy sexual behavior, (2) reproductive functionality, and (3) free from sexual-transmitted diseases (Sholeh, et al., 2019).

Empirical study revealed that improving in resilience was associated with decreasing in physical health symptoms (Osofsky, et al., 2019). Other empirical study found that physical activity in an alpine environment was associated with resilience and effected on quality of life which was partly mediated by resilience in patients with psychosomatic disorders and controls (Ower, et al., 2019). Based on the empirical facts, this article wants to examine the impact of reproductive health as part of physical health on family resilience.

H4: Reproductive health impact significantly on family resilience

Personal Financial Management is a strategic issue when dealing with economic crisis. People who manage financial well experience less financial stress, report more financial satisfaction, and have better health (Ksendzova, Donnelly, \& Howell, 2017). Every family should understand the importance and benefits of personal financial management. It helps family to achieve five lifetime financial goals: (1) pursuing maximum income and wealth, (2) practicing efficient consumption, (3) finding life satisfaction, (4) achieving financial security, and (5) accumulating wealth for pensions and inheritance (Priantinah, Aisyah, \& Nurim, 2019).

The factors can influence toward financial management behavior are 
financial attitude, financial socialization, financial experience, and financial literacy (Amaliawati \& Setiyani, 2018). There are five main steps in managing personal finances: (1) determining current financial position (2) setting future financial goals, (3) developing financial plans, (4) implementing financial plans, and (5) monitoring and evaluating implementation of financial plans (Manurung, 2008). This article reflects personal financial management in four dimensions: saving and investment, cash management, credit management, and insurance (Dew \& Xiao, 2011). Empirical study in Namibia which involved 147 caregivers for people with affected by HIV and AIDS found that financial status, social support, and health were related to the resilience of caregivers (Kalomo, Lee, Lightfoot, \& Freeman, 2018). Based on the empirical facts, this article plan to test statistically the impact of personal financial management on family resilience.

H5: Personal financial management impact significantly on family resilience

\section{Methodology}

This article is based on a quantitative and cross-sectional study by utilizing online questionnaire for gathering the data. Convenience approach were used as sampling methods. The digital questionnaire was distributed to the alumni of Pendidikan Kepemimpinanan Pemuda dalam Rumah Tangga (PKPRT) leadership programs for the youth in the family. The programs were conducted in 2019 by Kemenpora (Indonesia Youth and Sport Ministry) and were attended by the selected young people and families from all over Indonesia.

The study involved 296 respondents. They are generally male $(59 \%)$, and millennials who less than 41 years old $(80 \%)$, They have bachelor's degree as educational background (82\%) and single who plan to get married soon in 2020 $(58 \%)$. They are Muslim (98\%) and stay in Java $(75 \%)$. The complete description about the respondents is shown in Table 1. Table 1 Respondent Profile

\begin{tabular}{|l|l|l|l|l|}
\hline Profile of Respondents & Male & 173 & $59 \%$ & $59 \%$ \\
\hline \multirow{5}{*}{ Gender } & Female & 123 & $41 \%$ & $100 \%$ \\
\hline \multirow{5}{*}{ Age } & Less than 20 & 20 & $7 \%$ & $7 \%$ \\
\cline { 2 - 5 } & $21-30$ & 174 & $59 \%$ & $66 \%$ \\
\cline { 2 - 5 } & $31-40$ & 44 & $15 \%$ & $80 \%$ \\
\cline { 2 - 5 } & $41-50$ & 34 & $11 \%$ & $92 \%$ \\
\cline { 2 - 5 } & $51-60$ & 20 & $7 \%$ & $99 \%$ \\
\cline { 2 - 5 } & More than 60 & 4 & $1 \%$ & $100 \%$ \\
\hline \multirow{5}{*}{ Education } & High School & 94 & $32 \%$ & $32 \%$ \\
\cline { 2 - 5 } & Diploma & 11 & $4 \%$ & $35 \%$ \\
\cline { 2 - 5 } & Bachelor & 137 & $46 \%$ & $82 \%$ \\
\cline { 2 - 5 } & Master & 48 & $16 \%$ & $98 \%$ \\
\cline { 2 - 5 } & Doctoral & 6 & $2 \%$ & $100 \%$ \\
\hline \multirow{5}{*}{ Larital Status } & Single (plan to married) & 173 & $58 \%$ & $58 \%$ \\
\cline { 2 - 5 } & Married & 117 & $40 \%$ & $98 \%$ \\
\cline { 2 - 5 } & Others & 5 & $2 \%$ & $100 \%$ \\
\hline \multirow{2}{*}{ Sumatera } & 31 & $10 \%$ & $10 \%$ \\
\cline { 2 - 5 } & Java & 222 & $75 \%$ & $85 \%$ \\
\hline
\end{tabular}




\begin{tabular}{|l|l|l|l|l|}
\hline \multirow{5}{*}{} & Kalimantan & 13 & $4 \%$ & $90 \%$ \\
\cline { 2 - 5 } & Sulawesi & 18 & $6 \%$ & $96 \%$ \\
\cline { 2 - 5 } & Papua and Rest of Indonesia & 12 & $4 \%$ & $100 \%$ \\
\hline \multirow{5}{*}{ Number of Children } & Without Child & 188 & $64 \%$ & $64 \%$ \\
\cline { 2 - 5 } & One Child & 29 & $10 \%$ & $73 \%$ \\
\cline { 2 - 5 } & Two Children & 45 & $15 \%$ & $89 \%$ \\
\cline { 2 - 5 } & Three Children & 23 & $8 \%$ & $96 \%$ \\
\cline { 2 - 5 } & More Than Three Children & 11 & $4 \%$ & $100 \%$ \\
\hline \multirow{5}{*}{ Rears of marriage } & Plan to Get Married & 173 & $58 \%$ & $58 \%$ \\
\cline { 2 - 5 } & Less than 3 years & 66 & $22 \%$ & $81 \%$ \\
\cline { 2 - 5 } & $3-5$ years & 22 & $7 \%$ & $88 \%$ \\
\cline { 2 - 5 } & $6-10$ years & 21 & $7 \%$ & $95 \%$ \\
\cline { 2 - 5 } & More than 10 years & 287 & $97 \%$ & $97 \%$ \\
\hline & Moslem & 9 & $3 \%$ & $100 \%$ \\
\cline { 2 - 5 } & Christian or Catholics & & & $100 \%$ \\
\hline
\end{tabular}

This study develops research model which consist of six variables. Those variables are family resilience (FRES), the awareness of Islamic law on marriage (AISL), parenting quality (PARQ), psychological maturity (PMAT), reproductive health (REPH, and personal financial management (FINM). First order type was used to describe the research model. Most of variables were measured by instrument which adapted from the other studies. Only two variables - AISL and REPH were measured by instrument which developed on this study.

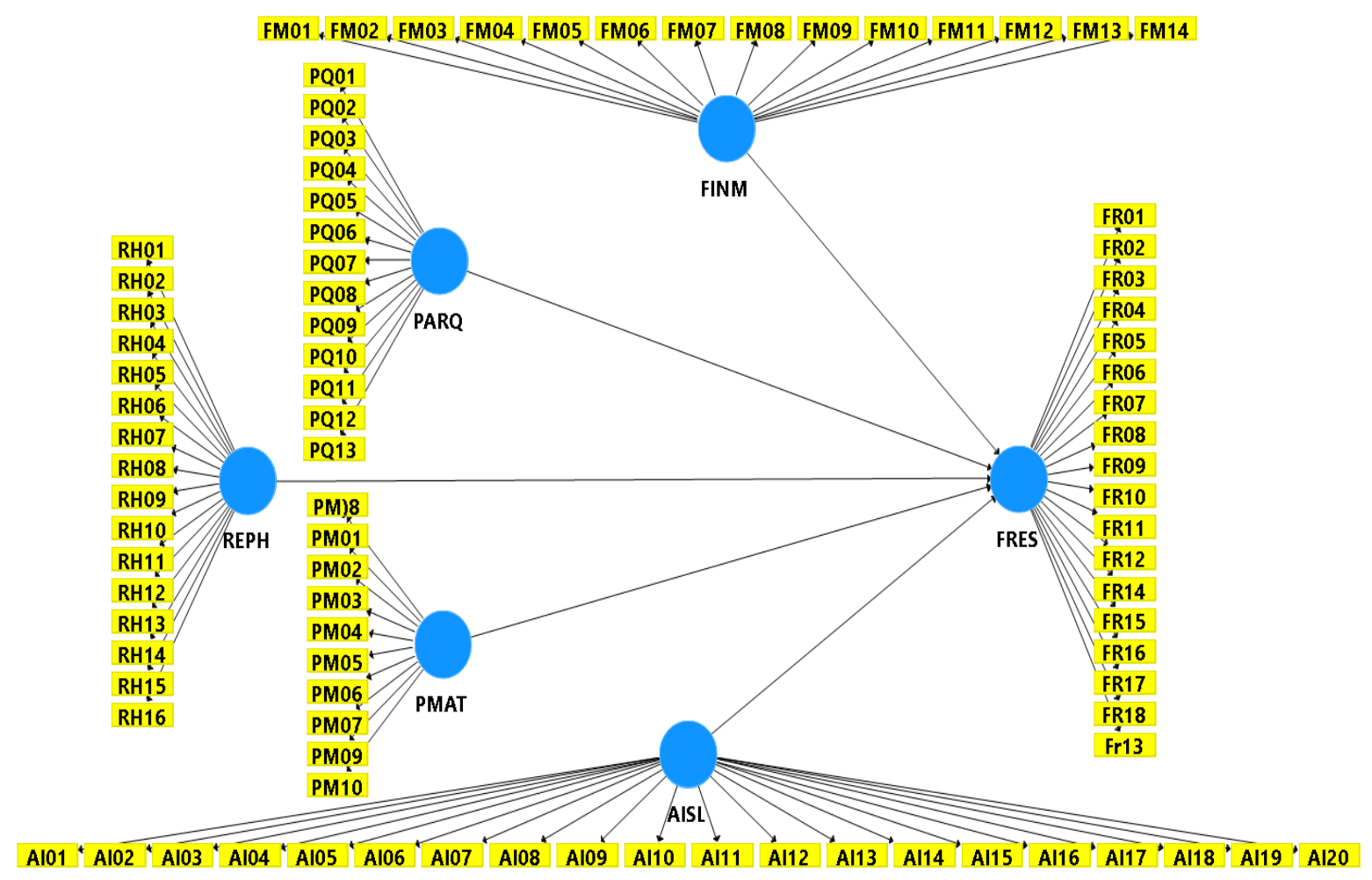

Figure 1 Research Model

FRES was measured by 18-indicators instrument which adopted from Family 
Resilience Assessment Scale (Nadrowska, Blazek, \& Lewandowska-Walter, 2020). PARQ was measured by 13-indicators instrument which adopted from Comprehensive Early Childhood Parenting Questionnaire (Verhoeven, Dekovic, Bodden, \& van Baar, 2017). PMAT was measured by 10-indicators instrument which adapted from Psychosocial Maturity (Greenberger, Josselon, Knerr, \& Knerr, 1975). FINM was measured 14-indicators instrument which adapted from Financial Management Behavior Scale (Dew \& Xiao, 2011).

The instrument of REPH was developed from Modul 3 Kesehatan Reproduksi - course material of PKPRT (Sholeh, et al., 2019). REPH is reflected into 16 indicators in three dimensions. AISL was developed from Modul 1 Hukum
Pernikahan - course material of PKPRT (Sholeh, et al., 2019) and a book about Islamic law on marriage and family (Sholeh, 2008) .AISL was reflected into 20 indicators in four dimensions. The whole variables, dimensions, and indicators of this study was displayed in Figure 1.

The validity and reliability analysis were run on the research model for ensuring that variables and indicators which are used in research model are valid and reliable. An indicator is valid, if its outer loading (OL) score is more than 0,60. A variable is valid AVE score is higher than 0,50. A variable is reliable, if Composite Reliability (CR) or Cronbach's Alpha (CA) score is higher than 0,7 . Table 2 shows the OL score of indicators and, AVE, CA, and CR score of all variables.

Table 2 Validity and Reliability Analysis

\begin{tabular}{|c|c|c|c|c|c|c|c|c|c|}
\hline Item & $\mathbf{O L}$ & CA & CR & $\begin{array}{l}\text { AV } \\
\text { E }\end{array}$ & Item & $\mathbf{O L}$ & $\mathbf{C A}$ & CR & AVE \\
\hline \multicolumn{5}{|c|}{ FAMILY RESILIENCE } & \multicolumn{5}{|c|}{ PARENTING QUALITY } \\
\hline $\begin{array}{l}\text { FR0 } \\
3\end{array}$ & $\begin{array}{l}0,6 \\
3\end{array}$ & \multirow{9}{*}{$\begin{array}{l}0,89 \\
3\end{array}$} & \multirow{9}{*}{$\begin{array}{l}0,91 \\
4\end{array}$} & \multirow{9}{*}{$\begin{array}{l}0,54 \\
4\end{array}$} & PQ13 & 0,62 & \multirow{7}{*}{0,855} & \multirow{7}{*}{0,890} & \multirow{7}{*}{0,539} \\
\hline $\begin{array}{l}\text { FR1 } \\
4\end{array}$ & $\begin{array}{l}0,6 \\
4\end{array}$ & & & & PQ01 & 0,63 & & & \\
\hline $\begin{array}{l}\text { FR0 } \\
7\end{array}$ & $\begin{array}{l}0,6 \\
5\end{array}$ & & & & PQ04 & 0,70 & & & \\
\hline $\begin{array}{l}\text { FR1 } \\
3\end{array}$ & $\begin{array}{l}0,7 \\
1\end{array}$ & & & & PQ02 & 0,74 & & & \\
\hline $\begin{array}{l}\text { FR1 } \\
6\end{array}$ & $\begin{array}{l}0,7 \\
7\end{array}$ & & & & PQ03 & 0,79 & & & \\
\hline $\begin{array}{l}\text { FR1 } \\
5\end{array}$ & $\begin{array}{l}0,7 \\
8\end{array}$ & & & & PQ06 & 0,81 & & & \\
\hline $\begin{array}{l}\text { FR1 } \\
0\end{array}$ & $\begin{array}{l}0,7 \\
9\end{array}$ & & & & PQ05 & 0,82 & & & \\
\hline $\begin{array}{l}\text { FR1 } \\
1\end{array}$ & $\begin{array}{l}0,8 \\
1\end{array}$ & & & & \multicolumn{5}{|c|}{ PSYCHOLOGICAL MATURITY } \\
\hline $\begin{array}{l}\text { FR1 } \\
2\end{array}$ & $\begin{array}{l}0,8 \\
4\end{array}$ & & & & PM03 & 0,65 & \multirow{3}{*}{0,699} & \multirow{3}{*}{0,815} & \multirow{3}{*}{0,530} \\
\hline $\begin{array}{l}\text { AWA } \\
\text { LAW } \\
\end{array}$ & RENH & SSO & ISL & MIC & PM08 & 0,67 & & & \\
\hline $\begin{array}{l}\text { AI1 } \\
3\end{array}$ & $\begin{array}{l}0,6 \\
0\end{array}$ & $\begin{array}{l}0,95 \\
1\end{array}$ & $\begin{array}{l}0,95 \\
6\end{array}$ & $\begin{array}{l}0,62 \\
6\end{array}$ & PM10 & 0,79 & & & \\
\hline
\end{tabular}




\begin{tabular}{|c|c|c|c|c|c|c|c|c|c|}
\hline $\begin{array}{l}\text { AI0 } \\
7\end{array}$ & $\begin{array}{l}0,7 \\
0\end{array}$ & & & & PM09 & 0,86 & & & \\
\hline $\begin{array}{l}\text { AI1 } \\
4\end{array}$ & $\begin{array}{l}0,7 \\
1\end{array}$ & & & & REPR & JCTII & HEALT & & \\
\hline $\begin{array}{l}\text { AI1 } \\
0\end{array}$ & $\begin{array}{l}0,7 \\
1\end{array}$ & & & & RH13 & 0,62 & \multirow{12}{*}{0,916} & \multirow{12}{*}{0,927} & \multirow{12}{*}{0,518} \\
\hline $\begin{array}{l}\mathrm{AI} 0 \\
9\end{array}$ & $\begin{array}{l}0,8 \\
0\end{array}$ & & & & RH01 & 0,64 & & & \\
\hline $\begin{array}{l}\text { AI2 } \\
0\end{array}$ & $\begin{array}{l}0,8 \\
1\end{array}$ & & & & RH08 & 0,65 & & & \\
\hline $\begin{array}{l}\mathrm{AI} 0 \\
8\end{array}$ & $\begin{array}{l}0,8 \\
1\end{array}$ & & & & RH15 & 0,68 & & & \\
\hline $\begin{array}{l}\text { AI1 } \\
5\end{array}$ & $\begin{array}{l}0,8 \\
2\end{array}$ & & & & RH07 & 0,69 & & & \\
\hline AI11 & $\begin{array}{l}0,8 \\
3\end{array}$ & & & & RH05 & 0,70 & & & \\
\hline $\begin{array}{l}\text { AI1 } \\
2\end{array}$ & $\begin{array}{l}0,8 \\
5\end{array}$ & & & & RH09 & 0,73 & & & \\
\hline $\begin{array}{l}\text { AI1 } \\
9\end{array}$ & $\begin{array}{l}0,8 \\
6\end{array}$ & & & & RH04 & 0,74 & & & \\
\hline $\begin{array}{l}\text { AI1 } \\
7\end{array}$ & $\begin{array}{l}0,8 \\
6\end{array}$ & & & & RH12 & 0,77 & & & \\
\hline $\begin{array}{l}\text { AI1 } \\
8\end{array}$ & $\begin{array}{l}0,8 \\
7\end{array}$ & & & & RH03 & 0,78 & & & \\
\hline \multicolumn{5}{|c|}{$\begin{array}{l}\text { PERSONAL FINANCIAL } \\
\text { MANAGEMENT }\end{array}$} & RH02 & 0,79 & & & \\
\hline $\begin{array}{l}\text { FM0 } \\
8\end{array}$ & $\begin{array}{l}0,6 \\
2\end{array}$ & \multirow{4}{*}{$\begin{array}{l}0,74 \\
5\end{array}$} & \multirow{4}{*}{$\begin{array}{l}0,84 \\
1\end{array}$} & \multirow{4}{*}{$\begin{array}{l}0,57 \\
2\end{array}$} & RH06 & 0,82 & & & \\
\hline $\begin{array}{l}\text { FM0 } \\
6\end{array}$ & $\begin{array}{l}0,7 \\
2\end{array}$ & & & & \multicolumn{5}{|c|}{$\begin{array}{l}\text { Note: } \mathrm{OL}=\text { Outer Loading, } \mathrm{CA}=\text { Cronbach's Alpha } \\
\mathrm{AVE}=\text { Average Variance Extracted }\end{array}$} \\
\hline $\begin{array}{l}\text { FM0 } \\
1\end{array}$ & $\begin{array}{l}0,8 \\
3\end{array}$ & & & & \multicolumn{5}{|c|}{$\mathrm{CR}=$ Composite Reliability } \\
\hline $\begin{array}{l}\text { FM0 } \\
2\end{array}$ & $\begin{array}{l}0,8 \\
4\end{array}$ & & & & & & & & \\
\hline
\end{tabular}

Based on OL or loading factor score: FRES has only 9 from 18 indicators, AISL has 13 from 13 indicators, PARQ has 7 form 13 indicators, REPH has 12 from 16 indicators, FINM has 4 from 14 indicators, and PMAT has 4 from 10 indicators are valid. Because those indicators have OL score more than 0,6. All variables are valid too. Because the AVE score of FRES, AISL, PARQ, REPH, PMAT, and FINM are more than 0,50. Table 3 shows discriminant validity. The diagonally bold scores are square root of AVE which indicate discriminant validity. A variable is discriminant valid, if the score is more than 0,7 or the highest score in the column. All variables are discriminant valid. Because the scores are more than 0,7 and as the highest score in the column.

Table 3 Discriminant Validity 


\begin{tabular}{|l|l|l|l|l|l|l|l|}
\hline & & {$[\mathbf{1}]$} & {$[\mathbf{2}]$} & {$[\mathbf{3}]$} & {$[\mathbf{4}]$} & {$[\mathbf{5}]$} & {$[\mathbf{6}]$} \\
\hline$[1]$ & Awareness of Islamic Law & $\mathbf{0 , 7 9}$ & & & & & \\
\hline$[2]$ & Personal Financial Management & 0,02 & $\mathbf{0 , 7 6}$ & & & & \\
\hline$[3]$ & Family Resilience & 0,18 & 0,29 & $\mathbf{0 , 7 4}$ & & & \\
\hline$[4]$ & Parenting Quality & 0,07 & 0,21 & 0,48 & $\mathbf{0 , 7 3}$ & & \\
\hline$[5]$ & Psychological Maturity & 0,14 & 0,52 & 0,27 & 0,24 & $\mathbf{0 , 7 3}$ & \\
\hline$[6]$ & Reproductive Health & $-0,19$ & $-0,17$ & $-0,16$ & $-0,12$ & $-0,15$ & $\mathbf{0 , 7 2}$ \\
\hline
\end{tabular}

All variables are reliable too. Because CA or CR score of FRES, AISL, PARQ, REPH, PMAT, and FINM are more than 0,70 . Based on the result of validity and reliability analysis, it is concluded that all indicators are valid, all variables are valid and reliable. All variables and its indicators are ready for testing the hypothesis.

\section{Result and Discussions}

By using the research model in Figure 2, the hypothesizes are tested. A hypothesis is accepted when path coefficient has $t$-Statistics more than 1,96 or $p$-Values lower than 0,05. By running bootstrap calculation with 500 subsamples on the structural model, the result is tabulated in Table 4. From six hypothesizes; two hypothesizes are rejected and four hypothesizes are accepted.

Table 4 Hypothesizes Testing

\begin{tabular}{|c|c|c|c|c|c|}
\hline \multicolumn{2}{|c|}{ Hypothesis } & $\begin{array}{l}\text { Path } \\
\text { Coefficient }\end{array}$ & $\begin{array}{l}t- \\
\text { Statistic }\end{array}$ & $\begin{array}{l}p \text { - } \\
\text { Values }\end{array}$ & Result \\
\hline $\begin{array}{l}\mathrm{H} \\
1\end{array}$ & $\begin{array}{l}\text { Awareness of Islamic Law } \rightarrow \text { Family } \\
\text { Resilience }\end{array}$ & 0,129 & 2,91 & 0,00 & $\begin{array}{l}\text { Accept } \\
\text { ed }\end{array}$ \\
\hline $\begin{array}{l}\mathrm{H} \\
2\end{array}$ & Parenting Quality $\rightarrow$ Family Resilience & 0,418 & 9,22 & 0,00 & $\begin{array}{l}\text { Accept } \\
\text { ed }\end{array}$ \\
\hline $\begin{array}{l}\mathrm{H} \\
3\end{array}$ & $\begin{array}{llll}\begin{array}{l}\text { Psychological } \\
\text { Resilience }\end{array} & \text { Maturity } & \rightarrow & \text { Family } \\
& & \end{array}$ & 0,059 & 1,03 & $\mathbf{0 , 3 0}$ & $\begin{array}{l}\text { Reject } \\
\text { ed }\end{array}$ \\
\hline $\begin{array}{l}\mathrm{H} \\
4 \\
\end{array}$ & Reproductive Health $\rightarrow$ Family Resilience & $-0,053$ & 0,84 & $\mathbf{0 , 4 0}$ & $\begin{array}{l}\text { Reject } \\
\text { ed }\end{array}$ \\
\hline $\begin{array}{l}\mathrm{H} \\
5\end{array}$ & $\begin{array}{l}\text { Personal Financial Management } \rightarrow \text { Family } \\
\text { Resilience }\end{array}$ & 0,159 & 2,90 & 0,00 & $\begin{array}{l}\text { Accept } \\
\text { ed }\end{array}$ \\
\hline
\end{tabular}

Table 4 shows that family resilience is influenced significantly by awareness of Islamic law (H1), parenting quality (H2), and personal financial management (H5). Family resilience is not influenced significantly by psychological maturity (H3) and reproductive health (H4).

Is the awareness of Islamic law on marriage the most influential factor? According to Table 4., path coefficient of AISL on FRES is 0,129 that is lower than path coefficient of PRQ on FRES $(0,418)$ and path coefficient of FINM on FRES
$(0,159)$. The most influential factor of family resilience is parenting quality. Personal financial management and awareness of Islamic law on marriage are influential factors on family resilience. Figure 2 show the adjusted $\mathrm{R}^{2}$ on FRES is 0,296 . It means that parenting quality, personal financial management, and awareness of Islamic law on marriage simultaneously impact on family resilience about 29,6\%. The other influential factors on family resilience about $69,4 \%$ are not identified yet by this 
empirical study.

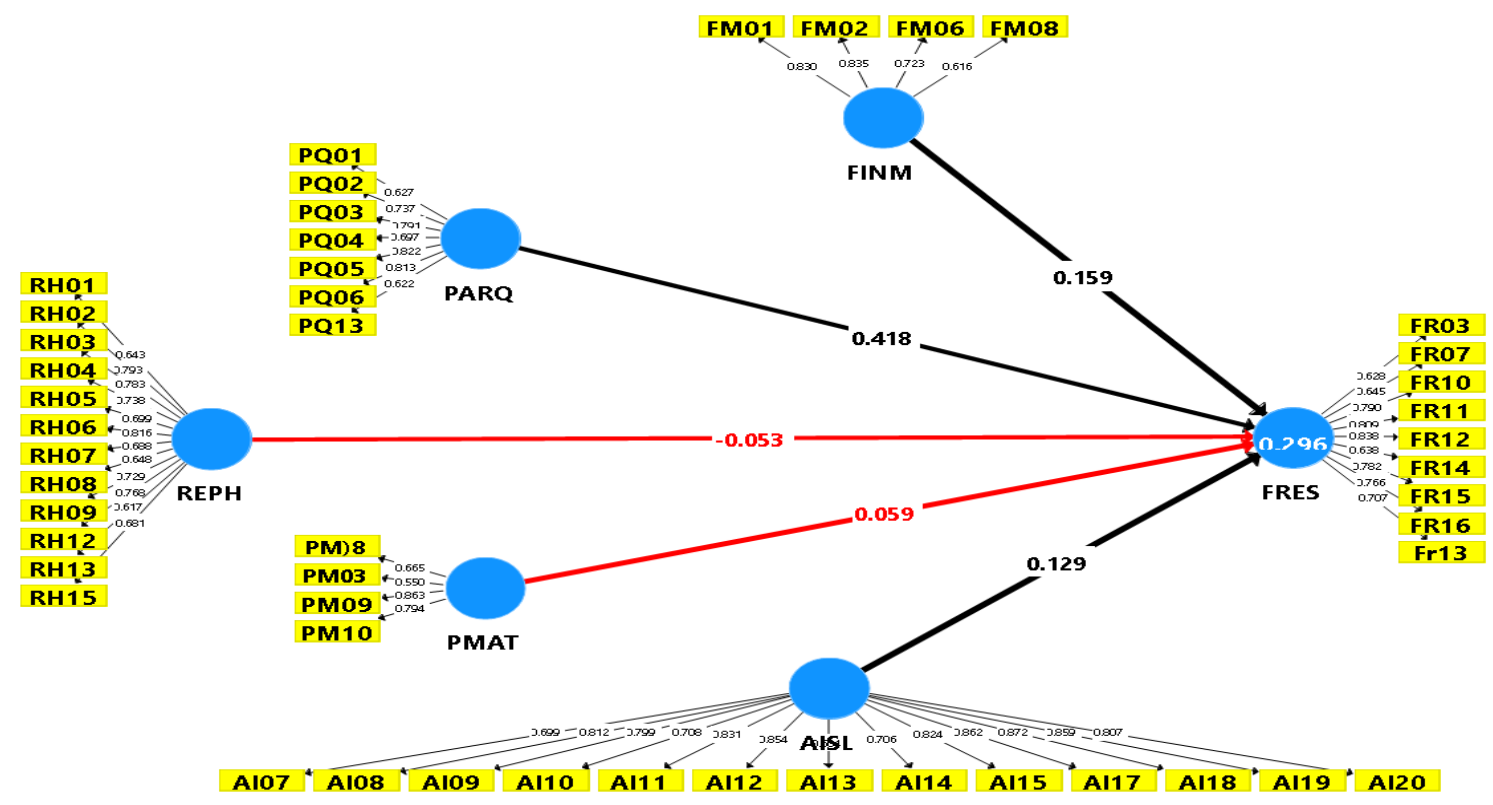

Figure 2 Structural Model

For developing the analysis, structural model was modified for examining impact of Islamic law awareness on other factors (PMAT, PARTQ, FINM) and impact of other factors (PMAT, FINM, REPH) on parenting quality. By computing bootstrap calculation on modified structural model, the result is illustrated in Figure 3. It explained that Islamic law awareness impacts on psychological maturity significantly then psychological maturity impacts significantly on parenting quality or personal financial management.

Although Islamic law awareness is not the most influential factor, but Islamic law awareness is the antecedent for psychological maturity. This result also explains that psychological maturity does not impact on family resilient directly, but indirectly. By influencing parenting quality or personal financial management significantly, then parenting quality or personal financial management impacts on family resilience significantly.
Psychological maturity impacts indirectly on family resilience.

Covid-19 crisis is demanding the resilience of all family in Indonesia. For strengthening the family resilience, awareness of Islamic law on marriage is an influential factor. The awareness of Islamic law on marriage is reflected into four dimension: (1) pre-requisites of marriage which indicated by AI01, AI02, AI03, AI04, AI05,AI05; (2) pillars of marriage which indicated by AI06, AI07, AI08, AI09, AI10; (3) husband-wife relationship which indicated by AI11, AI12, AI13, AI14, AI15, and (4) parenting and providing the living for family - which indicated by AI16, AI17, AI18, AI19, AI120. According to Structural Model (Figure 2), 13 indicators are valid for reflecting AISL as variable. Awareness of Islamic law on: (1) pillars of marriages, (2) husband-wife relationship, and (3) parenting and providing a living for family are relevant and impact significantly on family resilience 


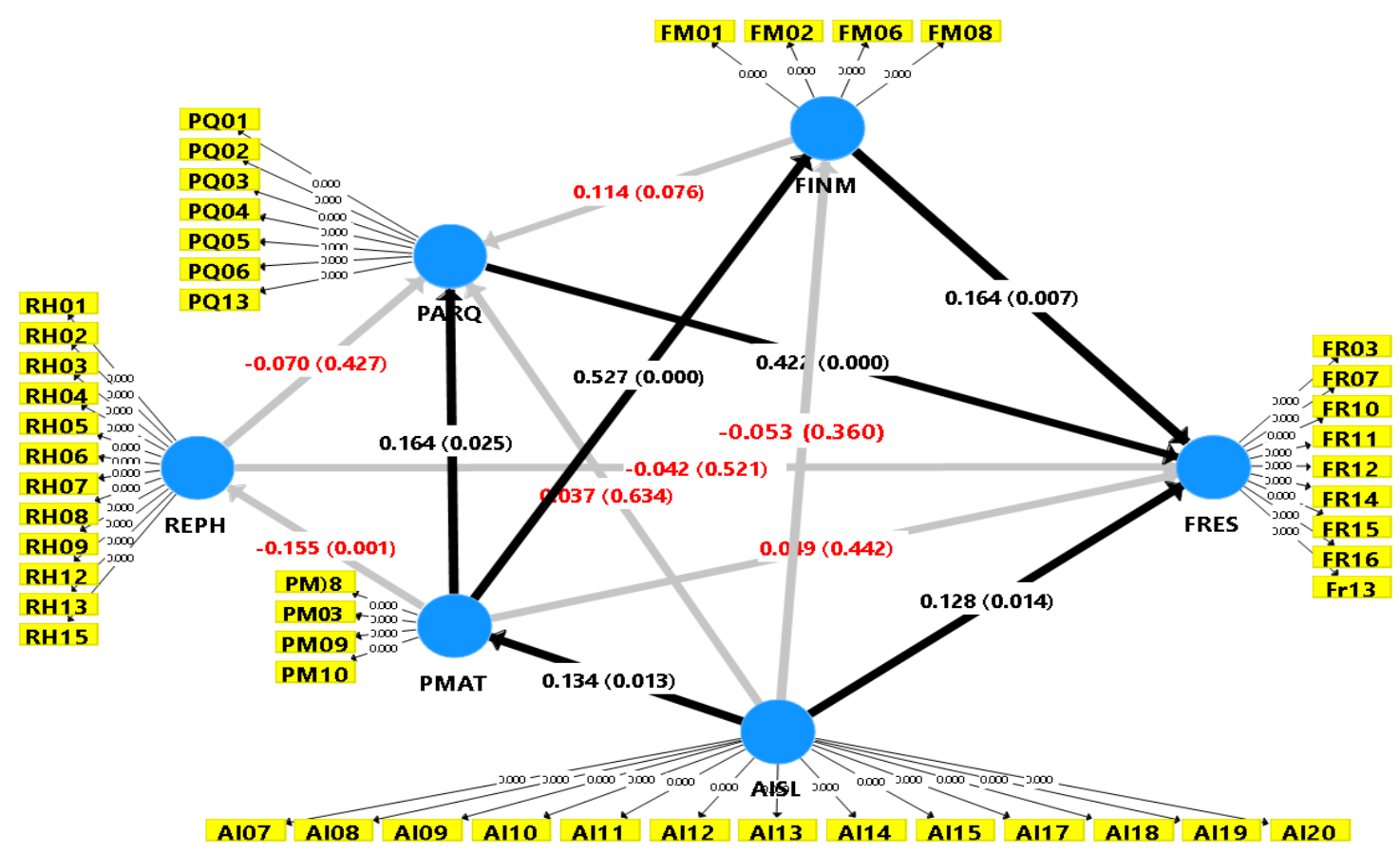

Figure 3 Modified Structural Model

For strengthening family resilience, the awareness of family - especially young people who plan to get married - on Islamic law should be intensified by various learning programs. The learning programs should focus on three subjects and 13 topics which shown in Table 5.

By leveraging the awareness of family in Islamic marriage law, it impacts on family resilience and psychological maturity. Psychological maturity is as psycho-social readiness for being responsible, independent, and confident. By improving psychological maturity, it impacts on parenting quality and personal financial management. Parenting quality provides the children with support, structure, stimulation, harsh discipline, and positive discipline in their developmental period. Personal financial management is related to personal ability of father and mother in family to manage their daily financial funds to fulfill their life needs in accordance with the level of income earned. By leveraging parenting quality and personal financial management, it impacts on family resilience - the family capability to withstand and rebound from stressful life challenges in Covid-19 times.

Table 5 Family Resilience related Islamic Law

\begin{tabular}{|l|l|}
\hline \multicolumn{2}{|l|}{ Subjects and Topics } \\
\hline \multicolumn{2}{|c|}{ Subject \#1: Pillars of Marriage } \\
\hline & Agreement from the bride and groom to get married (AI07) \\
\hline & The guardians (wali) for women (AI08) \\
\hline Witnesses (saksi) on both sides (AI09) \\
\hline & An explicit handover (ijab-kabul) between the guardian and the bachelor (AI10) \\
\hline Subject \#2: Husband-Wife Relationship \\
\hline$\quad$ Husband must provide protection for his wife and children (AI11) \\
\hline & Husbands must to fulfil the needs of the family according to his ability (AI12) \\
\hline & Wife must manage household affairs as well as possible (AI13) \\
\hline
\end{tabular}




\begin{tabular}{|l|l|}
\hline & Wife must ask permission from her husband for his personal interests (AI14) \\
\hline & Husband and wife treat each other with respect and affection (AI15) \\
\hline \multicolumn{2}{|c|}{ Subject \#3: Parenting and Providing a Living for The Family } \\
\hline & Father facilitates the needs of his children to grow and develop (AI17) \\
\hline & Father and mother educate and teach Islam to their children (AI18) \\
\hline & Father becomes the patron for his family in Islamic rituals (AI19) \\
\hline & Father and mother become the patrons for children in Islamic rituals (AI20) \\
\hline
\end{tabular}

\section{Conclusion}

Islamic law on marriage is an influential factor for family resilience in Indonesia during Covid-19 crisis. By leveraging the awareness of Islamic marriage law to the young people especially who plan to get marriage is essential effort for strengthening family resilience. Beside the awareness of Islamic marriage law, parenting quality and personal financial management of the family are the influential factors too. The awareness on Islamic marriage law also impacts on indirectly to parenting quality and personal financial management of the family. Although the awareness on Islamic marriage law is not the most influential factor, it is an essential factor which impact direct and indirectly on family resilience. For further research, respondents of study should be advanced to large number of family in Indonesia. Not only for the single and young family, but also for the all-stages family in the lifecycle. The sample should be randomly distributed by collaborating with BPS (national statistics body).

\section{References}

[1] Amaliawati, M., \& Setiyani, R. (2018). The influence of financial attitude , financial socialization, and financial experiences to financial management behavior with financial literacy as the mediation variable. KnE Social Sciences, 811-832.

[2] Bryan-Hancock, C., \& Casey, S. (2010). Psychological maturity of atrisk juveniles, young adults and adults: Implications for the justice system. Psychiatry, Psychology and Law, 17(1), 57-69.

[3] Danielewica-Mucha, D. (1991). Psychological maturity of young, divorcing people. Psychological Reports, 69(1), 255-260.

[4] Dew, J., \& Xiao, J. J. (2011). The financial management behavior scale: Development and validation. Journal of Financial Counseling and Planning, 22(1), 43.

[5] Firoze, H., \& Sathar, S. K. (2018). Impact of parenting styles on adolescent resilience. Indian Journal of Health and Wellbeing, 9(7), 937944.

[6] Greenberger, E., Josselon, R., Knerr, C., \& Knerr, B. (1975). The measurement and structure of psychosocial maturity. Journal of Youth and Adolescent, 4(2), 127-143.

[7] Jones, K. F., Dorsett, P., Simpson, G., \& Briggs, L. (2018). Moving forward on the journey: Spirituality and family resilience after spinal cord injury. Rehabilitation Psychology, 63(4), 521.

[8] Kalomo, E. N., Lee, K. H., Lightfoot, E., \& Freeman, R. (2018). Resilience among older caregiver in rural Namibia: The role of financial status, social support and health. Journal of Gerontological Social Work, 61(6), 605-622.

[9] Kasdi, A., \& Saifudin, S. (2020). Resilience of muslim families in the pandemic era: Indonesian millennials muslim community's response against Covid-19. Jurnal Penelitian, 81-94.

[10] Ksendzova, M., Donnelly, G. E., \& 3205 
Howell, R. T. (2017). A brief money management scale and its associatons with personality, financial health, and hypothetical debt repayment. Journal of Financial Counseling and Planning, 28(1), 62-75.

[11] Manurung, A. H. (2008). Financial planner: Panduan praktis mengelola keuangan keluarga. Jakarta: Penerbit Buku Kompas.

[12] McCubbin, M. A., \& McCubbin, H. I. (1991). Resilience in families: A conceptual model of family adjustment and adaptation in response to stress and crises. In Family Assessment: Resiliency, coping and adaptation (pp. 1-64).

[13] Morales-Vives, F., Camps, E., \& Duenas, J. M. (2020). Predicting academic achievement in adolescents: The role of maturity, intelligence, and personality. Psicothema, 32(1), 8491.

[14] Nadrowska, N., Blazek, M., \& Lewandowska-Walter, A. (2020). Polish adaptation of the Family Resilience Assessment Scale (FRAS) . Community Mental Health Journal.

[15] Nair, N., Taylor, Z. E., Evich, C. D., \& Jones, B. L. (2020). Relations of positive parenting, effortful control, and resilience in rural Midwestern Latin early adolescents. Children and Youth Service Review.

[16] Osofsky, H. J., Weems, C. F., Graham, R. A., Osofsky, J. D., Hansel, T. C., \& King, L. S. (2019). Perceptions of resilience and physical health symptom improvement following post disaster integrated health services. Disaster Medicine and Public Health Preparedness, 13(2), 223-229.

[17] Ower, C., Kemmler, G., Martini, C., Smitt, A., Sperner-Unterweger, B., \& Hufner, K. (2019). The effect of physical activity in an alpine environment on quality of life is mediated by resilience in patients with psychosomatic disorder and heakthy control. Europian Archieves of Psychiatry and Clinical Neuroscience, 269(5), 543-553.

[18] Priantinah, D., Aisyah, M. N., \& Nurim, Y. (2019). The analysis of technology acceptance model (TAM) for personal financial management on mobile application technology. International Conference on Banking, Accounting, Management and Economics. Atlantis Press.

[19] Sholeh, A. N. (2008). Fatwa-fatwa masalah pernikahan dan keluarga. Jakarta: Elsas.

[20] Sholeh, A. N., Jaswadi, Erlinda, Amriel, R. I., Pranawati, R., Maksum, M., . . . Helmi, M. (2019). Modul 1 Hukum Perkawinan - Pendidikan Kepemimpinan Pemuda dalam Rumah Tangga. Jakarta: Kementerian Pemuda dan Olahraga .

[21] Sholeh, A. N., Jaswadi, Erlinda, Amriel, R. I., Pranawati, R., Maksum, M., . . . Helmi, M. I. (2019). Modul 3 Kesehatan Reproduksi: Pendidikan Kepemimpinan Pemuda dalam Rumah Tangga. Jakarta: Kementerian Pemuda dan Olahraga.

[22] Sunarti, E. (2015). Ketahanan Keluarga Indonesia: Dari Kebijakan dan Penelitian Menuju Tindakan. Bogor.

[23] Susilowati, E., \& Azzasyofia, M. (2020). The parents stress level in facing children study from home in the early of Covid-19 pandemiic in Indonesia. International Journal of Science and Society, 3, 1-12.

[24] Verhoeven, M., Dekovic, M., Bodden, D., \& van Baar, A. L. (2017). Developmental and initial validation of the comprehensive early childhood parenting questionaire (CECPAQ) for parents of 1-4 year olds. European Journal of Developmental Psycgology, 14(2), 233-247.

[25] Walsh, F. (2016). Family resilience: A developmental systems framewrok. European Journal of Development 
Psychology, 13(3), 323-324.

[26] Yasien, S., Nasir, J. A., \& Shaheen, T. (2016). Relationship between psychological distress and resilience in rescue workers. Saudi Medical Journal, 37(7), 778. 